\title{
JEALOUSY IS EVER AT HAND AS AN INSPIRATION TO GENERATE PSYCHOLOGICALLY COMPLEX PLOT AND CHARACTER
}

\author{
CTursunova M., ORCID: 0000-0002-3552-4547, Uzbek State World languages University, \\ Tashkent,Uzbekistan,mukhlisa_vakhobovna@mail.ru
}

\section{РЕВНОСТЬ ВСЕГДА ПОД РУКОЙ, КАК ВДОХНОВЕНИЕ ДЛЯ СОЗДАНИЯ ПСИХОЛОГО-СЛОЖНОГО СЮЖЕТА И ПЕРСОНАЖА}

\author{
СТрурсунова M. В., ORCID: 0000-0002-3552-4547, Узбекский государственный университет \\ мировых языков, г. Ташкент, Узбекистан, mukhlisa_vakhobovna@mail.ru
}

Abstract. This article discusses the issue of jealousy and its importance in the process of literary plot shaping and character development. The three notable works by outstanding English and American writers such as the tragedy of "Othello" by W. Shakespeare, a short story - "The Ant and The Grasshopper" by W. S. Maugham and latest novel "The Finishing School" by Dame Muriel Spark are considered for the analysis of the issue in order to reveal how jealousy emerges and thus how it regulates the plot and disposes the psychology of the characters.

Аннотация. В данной статье обсуждается проблема ревности и ее значение в процессе формирования литературного сюжета и развития персонажа. Три примечательные работы выдающихся английских и американских писателей, такие как трагедия «Отелло» В. Шекспира, рассказ «Муравей и кузнечик» В. С. Моэм и последний роман Дамэ Мюриэл Спарк «Школа отделки» рассматриваются для анализа проблемы, чтобы показать, как возникает ревность и, следовательно, как она регулирует сюжет и располагает психологией персонажей.

Keywords: jealousy, envy, Iago, motive, The Finishing School.

Ключевые слова: ревность, зависть, Яго, мотив, Школа отделки.

According to literary critics, literature is permanently stimulated by the three dominant themes like war, mother and love. We are inclined to claim, that most psychologically challenging works are produced under the inspiration of several other aspects of the life. More specifically, these are the emotions that are emerged due to those social events and relationships, which give the inspiration to write. Were the humans emotionless, no war or any kind of relationship would be able to give literature such a global and essential status. There are a number of prevailing emotions in civilized societies, which the authors experiment in their creation, can raise the literary works to the rank of masterpieces. The most significant one among these feelings is jealousy.

Jealousy is a strong feeling of anger and sadness because someone has a better thing than you have. $[2,767]$ It is now definitely clear, that the primary meaning of the notion jealousy implies to a condition when a person is suffering due the material dissatisfaction. In addition, this very continuous dissatisfaction may further lead a person to get angrier and angrier, sadder and sadder up until he or she starts acting to reach that material possession that somebody else has. However, when we question the definition above to make it clear for our own sake, this mere definition becomes too narrow to explain what we have meant to indicate initially. In this complex situation, the analysis of jealous characters in several notable works can help us to understand the lifelong meaning of this term more thoroughly. Before discussing the term further, we are supposed to categorize the term in that extent we are about to use. There are two distinct types of jealousy - 
sexual jealousy and material jealousy and we would prefer to emphasize the latter one. Despite the fact that for many years (and still), in every surviving society, the former one has been considered as a typical human feature, even a positive one in some cases, whereas the latter one has been condemned due to the wrongful option to achieve something that has long belonged to somebody else. Jealousy operates like a powerful ambition that firstly damages its owner itself because jealousy is now a mixture of several strong feelings like anger, sadness and material dissatisfaction, which conducts a person into a psychologically sick condition that never gives a way to live a normal life. It works like a reasonable but evil motive to act faster, more efficiently and more determinedly to pursue the endless ambitions. Therefore, for Literature, jealousy driven motive has almost ever contributed as an efficient tool to form unprecedentedly complex characters such as, Iago in "Othello" by W. Shakespeare, George Ramsay in "The Ant, and the Grasshopper" by W. Somerset Maugham and Rowland Mahler in "The Finishing School" by Dame Muriel Spark. Moreover, much of the time of course, it is an old matter that the thing, which makes Iago - Iago or an ideal villain, is jealousy when he says:

One Michael Cassio, a Florentine,

A fellow almost damned in a fair wife,

That never set a squadron in the field,

Nor the division of a battle knows

As masterly as he: mere prattle, without practice

$\cdots$

$\mathrm{He}$, in good time, must his lieutenant be... [4, 5]

He argues that Othello being Moor himself has chosen an impractical fellow as his own lieutenant but not Iago. Iago deserves not only this position but also the Moor's position on his own claim, though. His jealous mind drives the whole plot of the tragedy. On the other hand when we take the different aspects of the issue into consideration, we are consciously able to perceive that the person has an option to follow two distinct ways, first - to choose the right way - to or to follow every evil mind and become corrupted in the end. Iago chooses to be villain. Therefore, in this case, we understand that we have to learn also, how to control our feelings or the consequences might be disastrous. He merely failed to regulate his jealous emotion. His jealousy made him villainous devil.

Intrinsically W.S. Maugham was able to show a different jealousy through the character of George Ramsay in "The Ant, and the Grasshopper". While challenging an old fable which portrays the ant as an ordinary industrious creature and grasshopper as a mere lazy, he led the reader to real scene where not all the ants are the innocent industrious ones but spent their whole life to prove to others that they are industrious while all grasshoppers are lazy miseries. However, in the end it became painstakingly obvious that when these lazy grasshoppers effortlessly reach something that the industrious ants had worked for the whole life, they "beat their clenched fists on the table" and agonizingly utter, "It's not fair, I tell you, it's not fair. Damn it, it's not fair" [3, 80] to prove their inner jealousy. Furthermore, the whole plot is arranged on his future expectations when he has everything through his hard and long working hours and his twin brother Tom has failed to prove to live a happy life by entertaining. George's jealousy caused his early aging, absorbed the years he might have lived happily, tempted him to work harder and harder in order to earn more so that one day he would have everything the best that nobody would ever possess and eventually turned him into a disgusting old man.

Yet, Muriel Spark successfully maintains all our expectations of jealousy driven plot in her "The Finishing School". Her main character, Rowland Mahler, near-to-retire professor, due to his illness decides to make a change in the hope that it might react positively on his health. Therefore, 
he starts writing a book but tends to lack stimulation for it. Unexpectedly, the situation gets tough when he meets eighteen-year-old college student, Chris Wiley, who is writing a historical novel, which has drawn the attention of several publishers. Rowland is shocked by Chris's extraordinary writing talent. Moreover, seeing how effortlessly he can produce brilliant fiction regardless of any literary theory, Rowland feels like bitter jealous. Unfortunately, it is not all. Chris arises a sexual interest to his teacher, which makes the plot psychologically much more complicated. Numerous dynamic passions plus envy that has started in the heart of the professor marks his instant psychological downfall.

Strong emotions like Jealousy or envy prolifically can drive the plot of any major novels like "Othello" and "The Finishing School" or a minor short story like "The Ant, and the Grasshopper" to its utmost level of beset exposition.

\section{References:}

1. Clanton, G. (2018). Jealousy and Envy. Classical and Contemporary Social Theory. Routledge, $1^{\text {st }}$ edition, the UK, 260.

2. Macmillan English Dictionary. (2002). Bloomsbury Publishing in Malaysia, 1692.

3. Maugham, W.S. (1976). Sixty-five short stories. William Heinemann Limited and Octopus Books Limited, Michelin House 81, Fulham Road, London, Great Britain, 937.

4. Shakespeare, W. (2005). Othello. Published by EMC/Paradigm Publishing 875, Montreal Way, St. Paul, Minnesota, the US, 301.

5. Spark, D.M. (2005). The Finishing School. Anchor, New York City, the United States, 181.

\section{Список литературы:}

1. Clanton G. Jealousy and Envy. Classical and Contemporary Social Theory. Routledge // 1st edition, the UK, 2018. P. 260.

2. Macmillan English Dictionary. Bloomsbury Publishing in Malaysia. 2002. 1692.

3. Maugham W. S. Sixty-five short stories // William Heinemann Limited and Octopus Books Limited, Michelin House 81, Fulham Road, London, Great Britain, 1976. 937.

4. Shakespeare W. Othello. Published by EMC/Paradigm Publishing 875, Montreal Way, St. Paul, Minnesota, the US, 2005. P. 301.

5. Spark D.M. The Finishing School // Anchor, New York City, the United States. 2005. P. 181.

Работа поступила

в редакцию 21.04.2019 2.
Принята к публикащии

25.04.2019 2.

Ссылка для цичтирования:

Tursunova M. Jealousy is Ever at Hand as an Inspiration to Generate Psychologically Complex Plot and Character // Бюллетень науки и практики. 2019. Т. 5. №6. С. 541-543. https://doi.org/10.33619/2414-2948/43/78

Cite as (APA):

Tursunova, M. (2019). Jealousy is Ever at Hand as an Inspiration to Generate Psychologically Complex Plot and Character. Bulletin of Science and Practice, 5(6), 541-543. https://doi.org/10.33619/2414-2948/43/78 